\title{
Assessing the Mobility of Lead, Copper and Cadmium in a Calcareous Soil of Port-au-Prince, Haiti ${ }^{\dagger}$
}

\section{Urbain Fifi $^{1, *}$, Thierry Winiarski ${ }^{2}$ and Evens Emmanuel ${ }^{1}$}

1 Université Quisqueya-LAQUE, 218, Avenue Jean Paul II, Haut de Turgeau, P.O. Box 796, Port-au-Prince, HT 6113, Haiti; E-Mail: evens.emmanuel@gmail.com

Université de Lyon-LEHNA, UMR 5023, ENTPE, Rue Maurice Audin, Vaulx-en-Velin CEDEX FR 69518, France; E-Mail: Thierry.winiarski@entpe.fr

$\dagger$ Based on Fifi, U.; Winiarski, T.; Emmanuel, E. Groundwater Vulnerability towards Pollutants from Urban Stormwater in Developing Countries-Study of Heavy Metals Adsorption on a Representative Soil of Port-au-Prince, Haiti. In Proceedings of Novatech 2010, Lyon, France, 27 June-1 July 2010 (in French).

* Author to whom correspondence should be addressed; E-Mail: urbain.fifi@gmail.com; Tel.: 50-9-3652-2993/50-9-2940-4587.

Received: 12 August 2013; in revised form: 28 October 2013 / Accepted: 28 October 2013 / Published: 4 November 2013

\begin{abstract}
The presence of heavy metals in the environment constitutes a potential source of both soil and groundwater pollution. This study has focused on the reactivity of lead $(\mathrm{Pb})$, copper $(\mathrm{Cu})$ and Cadmium $(\mathrm{Cd})$ during their transfer in a calcareous soil of Port-au-Prince (Haiti). Kinetic, monometal and competitive batch tests were carried out at $\mathrm{pH}$ 6.0. Two simplified models including pseudo-first-order and pseudo-second-order were used to fit the experimental data from kinetics adsorption batch tests. A good fit of these data was found with pseudo-second-order kinetic model which indicates the applicability of this model to describe the adsorption rates of these metals on the soil. Monometal batch tests indicated that both Langmuir and Freundlich models allowed a good fit for experimental data. On the basis of the maximum adsorption capacity $\left(q_{\mathrm{max}}\right)$, the order affinity of $\mathrm{Pb}, \mathrm{Cu}$ and $\mathrm{Cd}$ for the studied soil was $\mathrm{Pb}^{2+}>\mathrm{Cu}^{2+}>\mathrm{Cd}^{2+}$. Competitive sorption has proved that the competition between two or several cations on soils for the same active sites can decrease their $q_{\text {max }}$. These results show that, at high metal concentrations, $\mathrm{Cd}$ may pose more threat in soils and groundwater of Port-au-Prince than $\mathrm{Pb}$ and $\mathrm{Cu}$.
\end{abstract}


Keywords: lead; copper; cadmium; models; soils; sorption

\section{Introduction}

Heavy metals ions in soils have been a very useful indicator of environmental quality worldwide. Heavy metal ions are the most toxic inorganic pollutants which occur in soils and can be of natural or of anthropogenic origin [1-3]. Lead, copper, and cadmium belong to the group of serious hazardous heavy metals and are generally considered a threat to human health and ecosystems because of their potentially high toxicity [4]. Their mobility in soils may be controlled by different chemical mechanisms such as surface complex formation, ionic exchange, precipitation, and adsorption processes. However, the most important chemical process that affects heavy metal availability is adsorption onto soil solid phases [5]. Their solubility and bioavailability may also be controlled by soils characteristics [6], such as $\mathrm{pH}$, redox potential, clay minerals, soil organic matter, Fe and Mn oxides, and calcium carbonate. Therefore, metals adsorption and hence availability does not only depend on soil constituents (inorganic and organic), but also on the available metals, and their competition for soil sorption sites [5].

Many authors have investigated metals adsorption on different soils materials and under different experimental conditions [6-16]. Most trace element adsorption has been derived from studies conducted using single metal solutions [15,17]. Usually, single metal solutions have limited practical applications [18]. However, multi-metal solutions are extremely important for a better understanding of competitive sorption of metal ions. In addition, it is well-known that most heavy metal contamination in the surface environment is associated with a cocktail of contaminants rather than one metal.

Previous research at Port-au-Prince has showed an impact of groundwater quality related to the contribution of urban contaminants. For example, $\mathrm{Pb}$ concentrations ranging from $10 \mu \mathrm{g} \cdot \mathrm{L}^{-1}$ to $90 \mu \mathrm{g} \cdot \mathrm{L}^{-1}$ were measured in the drinking water of Port-au-Prince [19-21]. In this study, we have investigated the potential capacity of $\mathrm{Pb}, \mathrm{Cu}$ and $\mathrm{Cd}$ to sorb on soils of Cul-de-Sac plain. Knowledge about the mobility of these heavy metals in soils of Port-au-Prince may play a key role in the designing of control strategies to achieve better groundwater protection.

\section{Materials and Methods}

\subsection{Soil Samples and Characterization}

Three approximately 3-kg soil samples from $2 \mathrm{~m}$ apart of the same site were collected and combined prior to the experiments from the alluvial formations of the Cul-de-Sac plain at Port-au-Prince, which is not subjected to human activities (Figure 1). 
Figure 1. Aquifer systems of Cul-de-sac Plain, Haiti (sampling points ๑).

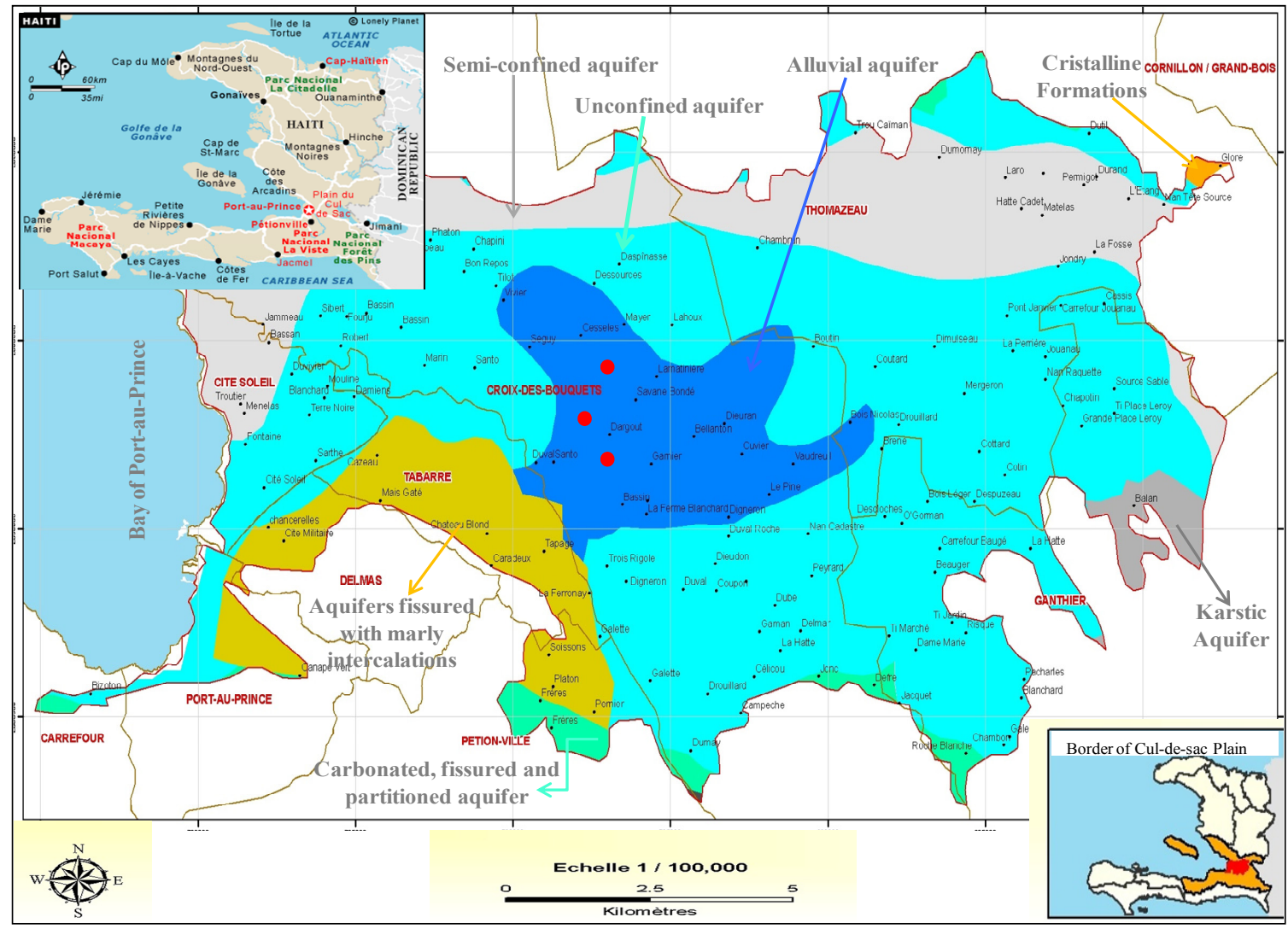

The $\leq 2 \mathrm{~mm}$ size soil fraction was used for laboratory experiments. This grain size is most reactive [13]. In general, coarse-grained soils exhibit lower tendency for heavy metal adsorption than fine-grained soils. The fine-grained soil fraction contains soil particles with large surface reactivities and surface areas. Clay minerals, iron and manganese oxyhydroxides, humic acids, and others minerals present have enhanced adsorption properties [1]. All the samples were air-dried at room temperature, passed through a $2 \mathrm{~mm}$ sieve, homogenized, and stored pending measurement of physicochemical properties such as $\mathrm{pH}$, organic carbon, clay, and $\mathrm{CaCO}_{3}$ using standard analytical methods. Soil $\mathrm{pH}$ was measured using a $\mathrm{pH}$ meter at a soil to solution ratio in both deionized water in 1:2.5 and $1 \mathrm{~mol} \cdot \mathrm{L}^{-1} \mathrm{KCl}$. Soil organic matter (OM) was determined by calcination at $550{ }^{\circ} \mathrm{C}$ for $2 \mathrm{~h}$. The inorganic carbon was determined using the calcimeter method and carbonate concentrations were calculating using Universal Gas Law [3]. The cation exchange capacity (CEC) of the soil was determined using the Metson method [22]. Concentrations of available heavy metals in the soil samples were determined by atomic absorption spectrometry (AAS) using NF ISO 11885 guidelines.

\subsection{Experimental Set-up}

Batch tests were carried out by equilibrating $5 \mathrm{~g}$ of soil with $50 \mathrm{~mL}$ of solutions containing different metal concentrations in $0.01 \mathrm{M} \mathrm{NaNO}_{3}$. All our experiments were performed at $\mathrm{pH} 6.0$ (adjusted using dilute $\mathrm{HNO}_{3}$ or $\mathrm{NaOH}$ ) in order to have a stable solution and avoid metals precipitation on hydroxides forms which can introduce uncertainty into the interpretation of results [23]. The metals cations were applied in the forms $\mathrm{Pb}\left(\mathrm{NO}_{3}\right)_{2}, \mathrm{Cu}\left(\mathrm{NO}_{3}\right) \cdot 3 \mathrm{H}_{2} \mathrm{O}$ and $\mathrm{Cd}\left(\mathrm{NO}_{3}\right)_{2} \cdot 4 \mathrm{H}_{2} \mathrm{O}$. Nitrates were used because these 
ions have no affinity for metals $[13,24]$. After equilibrium, the suspensions were filtered though a $0.45 \mu \mathrm{m}$ membrane, and samples were carefully dispensed to $50 \mathrm{~mL}$ polyethylene sample cups, acidified to $\mathrm{pH} 1.5-2$ using strong $\mathrm{HNO}_{3}$ and stored at $4{ }^{\circ} \mathrm{C}$ until the heavy metal ion measurements by AAS.

\subsubsection{Adsorption Kinetics}

Metal adsorption depends on the reaction kinetics and the time of contact between metal ions and soil. In this study, Kinetics batch tests were carried out at room temperature and samples were taking after $1 \mathrm{~min}$, $3 \mathrm{~min}, 8 \mathrm{~min}, 15 \mathrm{~min}, 30 \mathrm{~min}, 60 \mathrm{~min}, 120 \mathrm{~min}, 360 \mathrm{~min}, 720 \mathrm{~min}, 1,440 \mathrm{~min}, 2,880 \mathrm{~min}$ and 4,320 $\mathrm{min}$. The metal concentrations equilibrated with the soil sample were 250,80 and $123 \mathrm{mg} \cdot \mathrm{L}^{-1}$ of $\mathrm{Pb}, \mathrm{Cu}$ and Cd respectively. The metal suspensions were prepared and analyzed by AAS.

\subsubsection{Monometal Adsorption}

Monometal batch tests were performed over a $24 \mathrm{~h}$ period by shaking range concentrations of $\mathrm{Pb}$ $\left(0-186 \mathrm{mg} \cdot \mathrm{L}^{-1}\right), \mathrm{Cu}\left(0-57 \mathrm{mg} \cdot \mathrm{L}^{-1}\right)$ and $\mathrm{Cd}\left(0-101 \mathrm{mg} \cdot \mathrm{L}^{-1}\right)$ at room temperature. After equilibrium time, the suspensions were prepared for metal ions measurements by AAS. The amount of the metal ions sorbed by soil was calculated by:

$$
q_{e}=\left(C_{0}-C_{e}\right) \times V / W
$$

where $q_{e}$ is the amount of $\mathrm{Pb}^{2+}, \mathrm{Cu}^{2+}$ or $\mathrm{Cd}^{2+}$ adsorbed on the soil $\left(\mathrm{mg} \cdot \mathrm{g}^{-1}\right), C_{e}$ is the concentration of $\mathrm{Pb}^{2+}, \mathrm{Cu}^{2+}$ or $\mathrm{Cd}^{2+}$ at equilibrium $\left(\mathrm{mg} \cdot \mathrm{L}^{-1}\right), C_{0}$ is the initial concentration of $\mathrm{Pb}^{2+}, \mathrm{Cd}^{2+}$ or $\mathrm{Cu}^{2+}$ in solution $\left(\mathrm{mg} \cdot \mathrm{L}^{-1}\right), V$ is the solution volume $(\mathrm{mL})$, and $W$ is the weight of air-dried soil $(\mathrm{g})$.

\subsubsection{Competitive Adsorption}

$\mathrm{Bi}-$ and tri- metal batch tests were carried out by solubilizing a combination of either $\left(\mathrm{Pb}^{2+}-\mathrm{Cu}^{2+}\right)$, $\left(\mathrm{Pb}^{2+}-\mathrm{Cd}^{2+}\right),\left(\mathrm{Cu}^{2+}-\mathrm{Cd}^{2+}\right)$ and $\left(\mathrm{Pb}^{2+}-\mathrm{Cu}^{2+}-\mathrm{Cd}^{2+}\right)$. These experiments were conducted with the same operating conditions as for monometal batch tests in terms of volume $(50 \mathrm{~mL})$, soil sample weight $(5 \mathrm{~g})$, heavy metals concentrations ranges, $\mathrm{pH}(6.0)$ and agitation time (24 h).

\subsection{Theory}

To study the adsorption processes, simple mathematical expressions are usually applied to establish relationships between concentration of the adsorbent in the liquid phase and the solid phase at equilibrium and at constant temperature. During these experiments, adsorption processes do not always have time to reach equilibrium, but it is limited instead by reaction kinetics.

\subsubsection{Kinetics Models}

Kinetics batch tests were performed in order to evaluate the reaction rates of $\mathrm{Pb}, \mathrm{Cu}$ and $\mathrm{Cd}$ on the selected soil. Two simplified kinetics models including pseudo-first-order and pseudo-second-order were tested [25-28]. The pseudo-first-order equation is linearly expressed as: 


$$
\ln \left(Q_{e}-Q_{t}\right)=\ln Q_{e}-k_{1} t
$$

where $Q_{e}\left(\mathrm{mg} \cdot \mathrm{g}^{-1}\right)$ is the adsorption capacity at equilibrium, $Q_{t}\left(\mathrm{mg} \cdot \mathrm{g}^{-1}\right)$ is the amount of the metal adsorbed at time $t$, and $k_{1}\left(\mathrm{~min}^{-1}\right)$ is the rate constant of the pseudo-first-order equation. The values of $k_{1}$ can be obtained from the slope of the linear plot of $\ln \left(Q_{e}-Q_{t}\right) v s$. $t$ at different metal concentration. The linearised form of pseudo-second-order equation [25] is expressed as:

$$
t / Q_{t}=1 / k_{2} Q_{e}^{2}+t / Q_{e}
$$

where $k_{2}$ is the rate constant of pseudo-second-order kinetics. The values of $k_{2}\left(\mathrm{~g} \cdot \mathrm{mg} \cdot \mathrm{min}^{-1}\right)$ and $Q_{e}$ can be determined from the slope and intercept of the plot obtained by plotting $t / Q_{t} v s$. $t$ respectively.

\subsubsection{Isotherms Adsorption Models}

Langmuir and Freundlich models were used to study monometal isotherms of $\mathrm{Pb}^{2+}, \mathrm{Cd}^{2+}$ and $\mathrm{Cu}^{2+}$ on the soil [29]. The above two models are given, respectively, as follows:

$$
\begin{gathered}
q_{e}=Q_{\max } b C_{e} / 1+b C_{e} \\
q_{e}=k_{F} C_{e}^{1 / n}
\end{gathered}
$$

where $C_{e}\left(\mathrm{mg} \cdot \mathrm{L}^{-1}\right)$ and $q_{\mathrm{e}}\left(\mathrm{mg} \cdot \mathrm{g}^{-1}\right)$ are the equilibrium adsorbante concentrations in the aqueous and solid phases, respectively; $Q_{\max }$ is the maximum adsorption $\left(\mathrm{mg} \cdot \mathrm{g}^{-1}\right)$ and $\mathrm{b}\left(\mathrm{L} \cdot \mathrm{mg}^{-1}\right)$ is the adsorption equilibrium constant; $k_{F}\left(\mathrm{~L} \cdot \mathrm{mg}^{-1}\right)$ is the Freundlich distribution coefficient and $n$ is an empirical constant (unitless).

Jain and Snoeyink (JS) [30] have proposed a modified equation of the Langmuir model Equation (4) for bi-solute adsorption systems. The extended Langmuir model takes into consideration that the presence of other metals in solution can affect the apparent affinity of the metal for the adsorption on an active site [31]. The JS modified model equations is given by:

$$
\begin{gathered}
q_{1}=\left(Q_{\mathrm{m}, 1}-Q_{\mathrm{m}, 2}\right) b_{1} C_{1} / 1+b_{1} C_{1}+Q_{\mathrm{m}, 2} b_{1} C_{1} / 1+b_{1} C_{1}+b_{2} C_{2} \\
q_{2}=Q_{\mathrm{m}, 2} b_{2} C_{2} / 1+b_{1} C_{1}+b_{2} C_{2}
\end{gathered}
$$

were $q_{1}$ and $q_{2}$ are the amount of metals 1 and 2 adsorbed per unit weight of adsorbent at equilibrium concentrations $C_{1}$ and $C_{2}$. The first term of the Equation (6) is the Langmuir expression for the number of molecules of solute 1 that sorb without competition on the surface area and the term is proportional to $\left(Q_{\mathrm{m}, 1}-Q_{\mathrm{m}, 2}\right)$. The second term of this equation represents the number of molecules of solute 1 sorbed on the surface area proportional to $Q_{\mathrm{m}, 2}$ in competition with solute 2, and is based on the Langmuir model for competition adsorption. The number of molecules of solute 2 sorbed on the adsorbent surface is proportional to $Q_{\mathrm{m}, 2}$ in competition with solute 1, can be calculated from Equation (7). The JS model was used in this study to assess the bi-metal competitive adsorption of $\mathrm{Pb}, \mathrm{Cu}$ and $\mathrm{Cd}$ on the studied soil.

Experimental data from tri-metal batch tests was modeled using Langmuir extended model, as follows: 


$$
q_{e, i}=q_{m, i}^{0}\left[b_{i}^{0} C_{e, i} / 1+\sum_{j=1}^{N} b_{j}^{0} C_{e, j}\right]
$$

where $q_{m, i}^{0}, b_{i}^{0}$ and $b_{j}^{0}$ are Langmuir extended parameters obtained from Equation (4) in monometal batch tests and $C_{e, i}$ and $C_{e, j}$ are respectively the concentrations of metals $i$ and $j$ from tri-metal batch tests after equilibrium.

\section{Results and Discussion}

\subsection{Soil Characteristics}

Table 1 shows the physicochemical characteristics of the studied soil. The results confirmed that the soil have an alkaline $\mathrm{pH}$ value (8.26) due the presence of the free $\mathrm{CaCO}_{3}\left(343 \mathrm{~g} \cdot \mathrm{kg}^{-1}\right)$. The $\mathrm{CaCO}_{3}$ value is consistent with a watershed rich in carbonate formations. Data indicate abundant organic matter (OM) $\left(58 \mathrm{~g} \cdot \mathrm{kg}^{-1}\right)$ and Cation Exchange Capacity (CEC) of the soil sample. The CEC can be estimated by the clay content and organic matter. Therefore, soils with very little OM have a low CEC, but heavy clay soils with high levels of $\mathrm{OM}$ would have a much greater capacity to sorb cations. Soil samples had $\mathrm{Pb}$ and $\mathrm{Cd}$ concentrations below detection limits. These values have justified the choice of soil sample area. $\mathrm{Cu}$ concentrations $\left(61.4 \mathrm{mg} \cdot \mathrm{kg}^{-1}\right)$ are probably related to natural concentrations.

Table 1. Physicochemical characteristics of soil from Cul-de-Sac plain.

\begin{tabular}{|c|c|c|}
\hline Parameters & Concentration & Standards and analysis methods \\
\hline $\mathrm{pH}-\mathrm{H}_{2} \mathrm{O}$ & 8.26 & AFNOR X31-104 \\
\hline $\mathrm{pH}-\mathrm{KCl}$ & 7.46 & AFNOR X31-104 \\
\hline $\mathrm{CaCO}_{3}\left(\mathrm{~g} \cdot \mathrm{kg}^{-1}\right)$ & 343.00 & AFNOR X31-105 \\
\hline Organic carbon $\left(\mathrm{g} \cdot \mathrm{kg}^{-1}\right)$ & 100.00 & AFNOR X31-106 \\
\hline Organic matter $\left(\mathrm{g} \cdot \mathrm{kg}^{-1}\right)$ & 57.85 & Calcination at $550{ }^{\circ} \mathrm{C}$ \\
\hline Clay $\left(g \cdot \mathrm{kg}^{-1}\right)$ & 17.00 & AFNOR X31-107 \\
\hline $\mathrm{CEC}\left(\mathrm{meq} \cdot \mathrm{kg}^{-1}\right)$ & 135.00 & Metson Method AFNOR X31-130 \\
\hline Surface area $\left(\mathrm{m}^{2} \cdot \mathrm{g}^{-1}\right)$ & 9.48 & B.E.T Method \\
\hline Total $\mathrm{Ca}\left(\mathrm{g} \cdot \mathrm{kg}^{-1}\right)$ & 9.67 & AFNOR X31-108 \\
\hline Total $\mathrm{Mg}\left(\mathrm{g} \cdot \mathrm{kg}^{-1}\right)$ & 0.45 & AFNOR X31-108 \\
\hline Total $\mathrm{K}\left(\mathrm{g} \cdot \mathrm{kg}^{-1}\right)$ & 0.051 & AFNOR X31-108 \\
\hline Total $\mathrm{Cr}\left(\mathrm{mg} \cdot \mathrm{kg}^{-1}\right)$ & 17.40 & NF ISO 11885 \\
\hline Total $\mathrm{Cu}\left(\mathrm{mg} \cdot \mathrm{kg}^{-1}\right)$ & 61.40 & NF ISO 11885 \\
\hline Total Ni $\left(\mathrm{mg} \cdot \mathrm{kg}^{-1}\right)$ & 24.10 & NF ISO 11885 \\
\hline Total $\mathrm{Zn}\left(\mathrm{mg} \cdot \mathrm{kg}^{-1}\right)$ & 28.10 & NF ISO 11885 \\
\hline Total Cd $\left(\mathrm{mg} \cdot \mathrm{kg}^{-1}\right)$ & $\mathrm{Ud}$ * & NF ISO 11885 \\
\hline Total $\mathrm{Pb}\left(\mathrm{mg} \cdot \mathrm{kg}^{-1}\right)$ & $\mathrm{Ud}$ & NF ISO 11885 \\
\hline Total $\mathrm{Hg}\left(\mathrm{mg} \cdot \mathrm{kg}^{-1}\right)$ & $\mathrm{Ud}$ & NF ISO 11885 \\
\hline Total Se $\left(\mathrm{mg} \cdot \mathrm{kg}^{-1}\right)$ & $\mathrm{Ud}$ & NF ISO 11885 \\
\hline
\end{tabular}

* Undetected. 


\subsection{Kinetics}

The adsorption rates of the three metals have been evaluated using Equations (2) and (3). The obtained parameters for pseudo-first and second order are given in Table 2. The low values of correlation coefficients indicate that the pseudo-first order model is inappropriate to describe the adsorption rates processes.

Table 2. Constants and correlation coefficients obtained by pseudo-first-order and pseudo-second-order kinetics models.

\begin{tabular}{cccccc}
\hline \multirow{2}{*}{ Metal ions } & \multicolumn{4}{c}{ Pseudo-first order } & \multicolumn{3}{c}{ Pseudo-second order } \\
\cline { 2 - 6 } & $\boldsymbol{K}_{\mathbf{1}}\left(\mathbf{m i n}^{\mathbf{- 1}}\right)$ & $\boldsymbol{R}_{\mathbf{1}}^{\mathbf{2}}$ & $\boldsymbol{Q}_{\mathbf{e}}\left(\mathbf{m g} \cdot \mathbf{g}^{\mathbf{- 1}}\right)$ & $\boldsymbol{K}_{\mathbf{2}}\left(\mathbf{g} \cdot \mathbf{m g} \mathbf{~}^{-\mathbf{1}} \cdot \mathbf{m i n}\right)$ & $\boldsymbol{R}_{\mathbf{2}}^{\mathbf{2}}$ \\
\hline $\mathrm{Pb}^{2+}$ & 0.00139 & 0.66 & 2.50 & 0.25 & 1.00 \\
$\mathrm{Cu}^{2+}$ & 0.00147 & 0.68 & 0.79 & 0.77 & 1.00 \\
$\mathrm{Cd}^{2+}$ & 0.00010 & 0.83 & 1.24 & 0.01 & 0.99 \\
$\mathrm{~Pb}^{2+}\left(\mathrm{Pb}^{2+}-\mathrm{Cu}^{2+}-\mathrm{Cd}^{2+}\right)$ & 0.00047 & 0.48 & 2.61 & 0.075 & 1.00 \\
$\mathrm{Cu}^{2+}\left(\mathrm{Cu}^{2+}-\mathrm{Pb}^{2+}-\mathrm{Cd}^{2+}\right)$ & 0.0012 & 0.71 & 0.86 & 0.055 & 0.99 \\
$\mathrm{Cd}^{2+}\left(\mathrm{Cd}^{2+}-\mathrm{Pb}^{2+}-\mathrm{Cu}^{2+}\right)$ & 0.00073 & 0.91 & 1.58 & 0.002 & 0.94 \\
\hline
\end{tabular}

The pseudo-second order kinetic plots $\left(t / q_{\mathrm{t}} v s . t\right)$ appeared to give a better understanding of the interactions (Figure 2). However, the good fitting $\left(R^{2}=1.0\right)$ of the experimental data for $\mathrm{Pb}^{2+}$ and $\mathrm{Cu}^{2+}$ ions with pseudo-second-order model indicates the applicability of this model to predict adsorption rates for each metal on the soil. It was denoted that a pseudo-second-order approach can sometimes provide a better description of the adsorption kinetics [32,33].

Figure 2. Pseudo-second order kinetics plots of $\mathrm{Pb}^{2+}, \mathrm{Cu}^{2+}$ and $\mathrm{Cd}^{2+}$ in the soil: (a) Monometal batch tests; (b) Tri-metal batch tests.
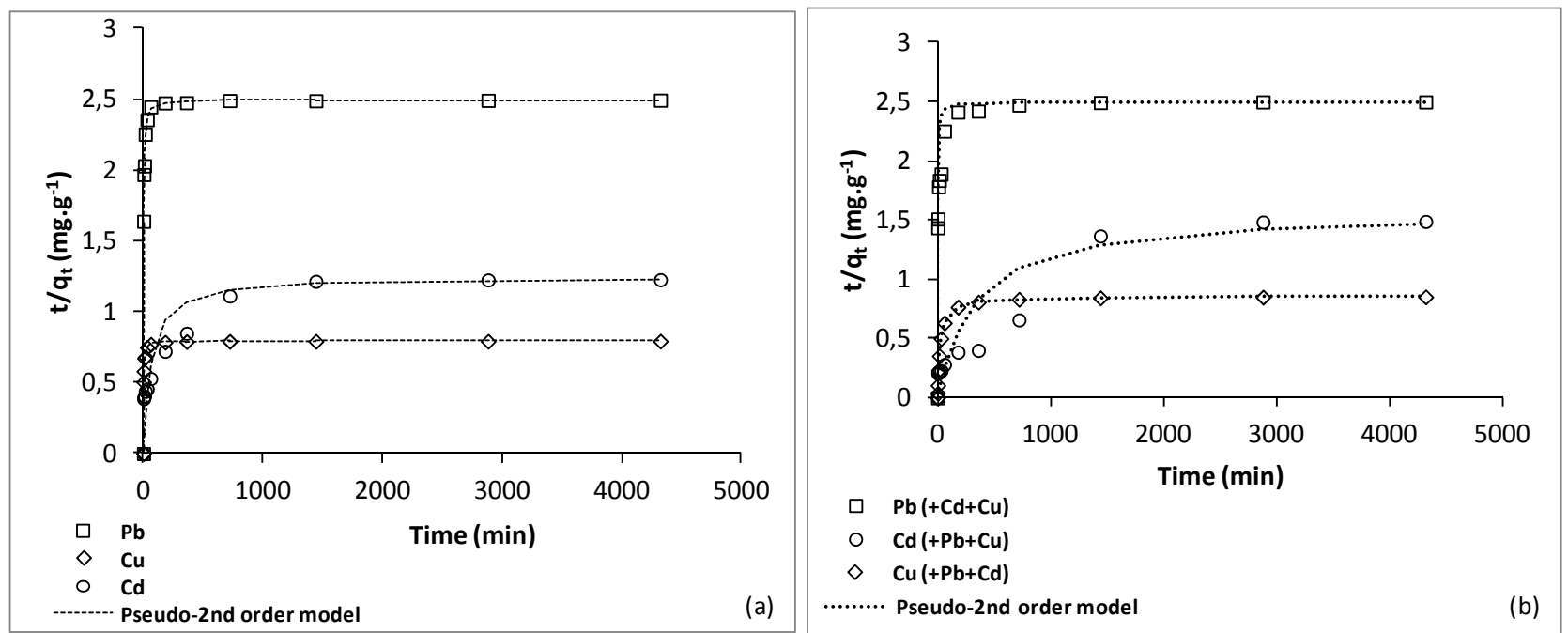

Results from monometal batch tests have showed that $\mathrm{Pb}$ displayed the fastest adsorption rates comparatively to $\mathrm{Cu}$ and $\mathrm{Cd}$ (Figure $2 \mathrm{a}$ ). Therefore, at about $180 \mathrm{~min}$, the maximum adsorption capacity of $\mathrm{Pb}$ and $\mathrm{Cu}$ were obtained whereas $\mathrm{Cd}$ had continued to sorb over 4,320 min. Results from tri-metal batch tests have proved that a decrease of adsorption rates for the three metals (Figure $2 b$ ). These results 
have showed that the maximum adsorption capacity for $\mathrm{Pb}, \mathrm{Cu}$ and $\mathrm{Cd}$ was obtained respectively at 2,880, 4,320 and over 4,320 min. These results showed that when two or more metal ions are together in soils, their adsorption rates is decreased each other. Therefore, their mobility in soils can be limited by competition for the adsorption sites and they don't represent a potential risk at short-term for groundwater of Port-au-Prince.

\subsection{Monometal Adsorption}

The adsorption isotherms of Langmuir and Freundlich for $\mathrm{Pb}, \mathrm{Cu}$ and $\mathrm{Cd}$ ions at $\mathrm{pH} 6.0$ are illustrated in Figures 3 and 4, respectively. These isotherms represent the adsorption behavior of these metals on the soil as a function of increasing aqueous metal ion concentration after equilibrium. The results indicated that the adsorption data of the three metals were well correlated with Langmuir and Freundlich models. The Freundlich equation habitually provides a good description of adsorption onto heterogeneous solid surfaces $[34,35]$. However, the adsorption of $\mathrm{Pb}^{2+}$ data gave a good satisfactory fit with both Langmuir $\left(R_{\mathrm{L}}{ }^{2}=0.91\right)$ and Freundlich $\left(R_{\mathrm{F}}{ }^{2}=0.91\right)$. The $q_{\max }, b, R_{\mathrm{L}}{ }^{2}$ (correlation coefficient for Langmuir isotherm); $K_{\mathrm{F}}, \mathrm{n}$ and $R_{\mathrm{F}}{ }^{2}$ (correlation coefficient for Freundlich isotherm) are given in Table 3.

Freundlich parameters $\left(K_{\mathrm{F}}\right.$ and $\left.n\right)$ indicate whether the nature of adsorption is either favorable or unfavorable [36]. The values of $n$ are less than 1 indicate a favorable adsorption mechanisms and formation of relatively stronger bonds between the adsorbents [37]. In Table 3, the low values of $n(n<1)$ for $\mathrm{Pb}^{2+}$ and $\mathrm{Cd}^{2+}$ indicate that adsorption intensity is favorable at high range of concentrations studied, while for $\mathrm{Cu} 2+(\mathrm{n}>1)$ means that adsorption intensity is unfavorable at high concentrations but much less at lower concentrations. Some studies on other sites area have supported this conclusion [34,36,38,39].

Figure 3. Freundlich adsorption isotherm for $\mathrm{Pb}^{2+} \mathrm{Cu}^{2+}$ and $\mathrm{Cd}^{2+}$ on the studied soil at $\mathrm{pH} 6$.

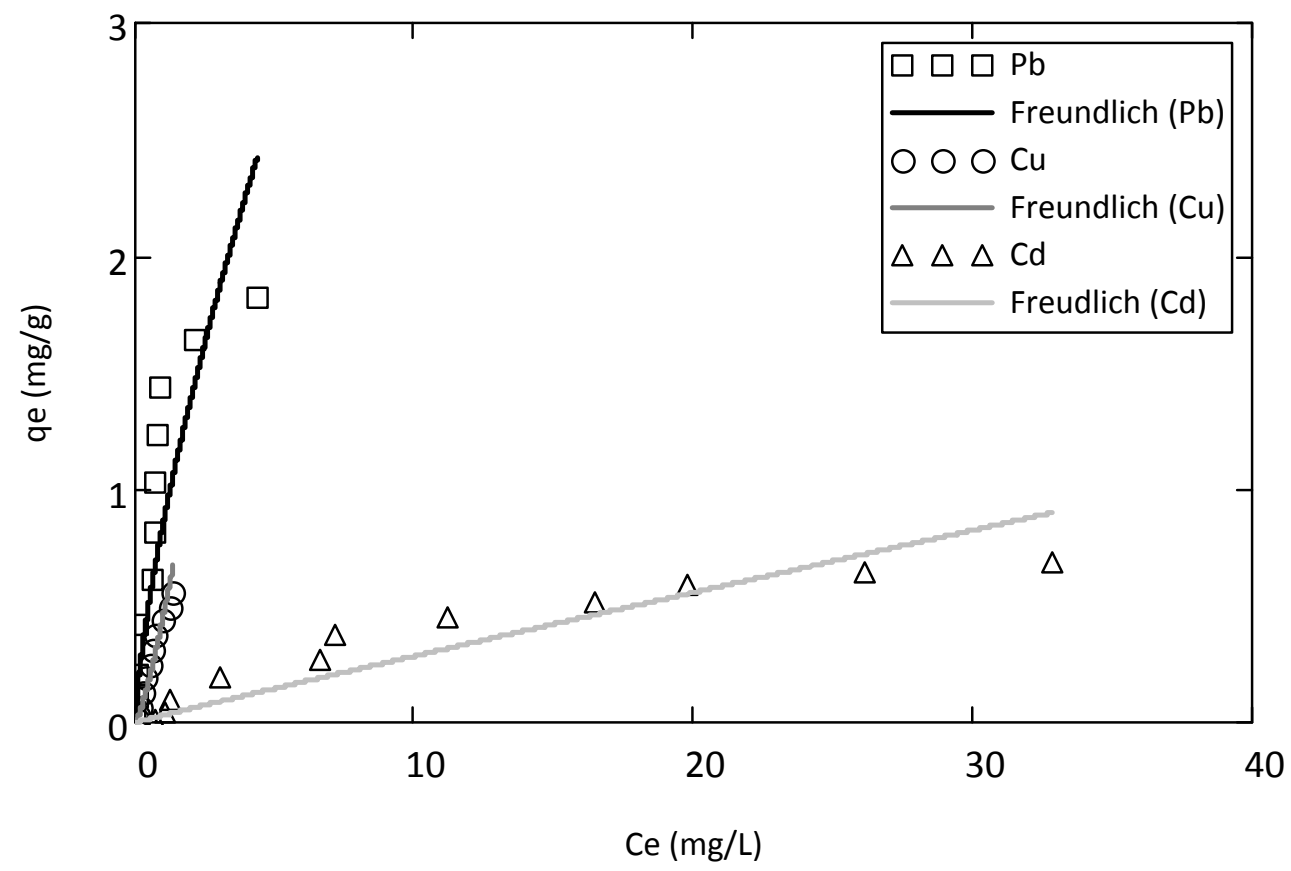


Figure 4. Langmuir adsorption model for $\mathrm{Pb}^{2+}, \mathrm{Cu}^{2+}$ and $\mathrm{Cd}^{2+}$ on the studied soil at $\mathrm{pH} 6$.

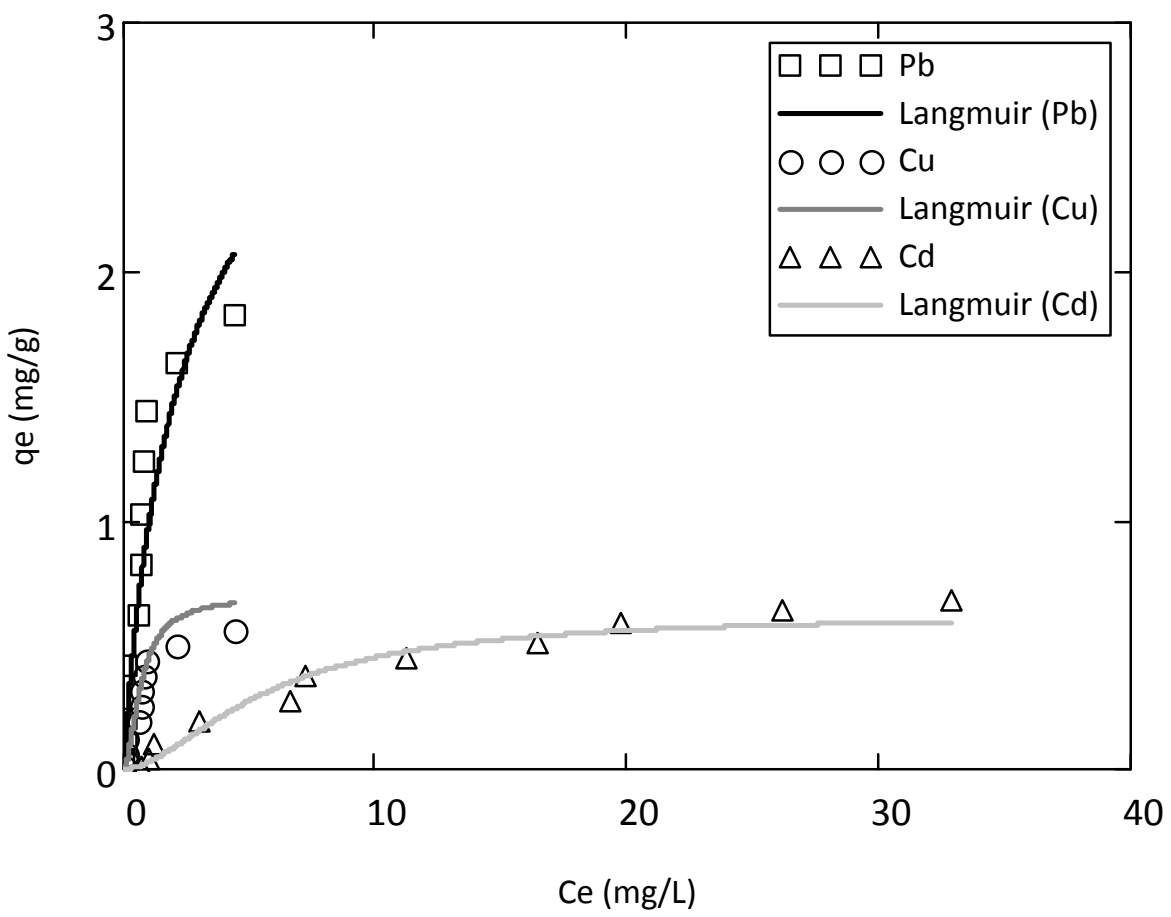

The $q_{\max }$, from the Langmuir equation, may be a useful parameter for comparing the potential capacity of the soil. Among all the three metals, $\mathrm{Pb}$ showed the highest value of adsorption maximum $\left(q_{\max }\right)$. On the basis on the $q_{\max }$ value, the order selectivity of these metals for the soil is $\mathrm{Pb}^{2+}>\mathrm{Cu}^{2+}>\mathrm{Cd}^{2+}$. The selectivity order can be influenced by the valency and the ionic size of the heavy metals once hydrated [40,41]. Then, smaller ions with the same valency, such as $\mathrm{Cd}$ compared with $\mathrm{Pb}$, have higher charge densities and attract more water molecules, resulting in a larger hydrated radius. Metals with higher hydrated radius exert weaker Columbic forces of attraction [42]. Therefore, $\mathrm{Cd}$ ( $0.23 \mathrm{~nm}$ radius) is expected to be mobile that $\mathrm{Pb}(0.187 \mathrm{~nm}$ radius $)$ because of its larger hydrated radius. In order case, the higher affinity of the soil for $\mathrm{Pb}$ may probably due to the existence of a greater number of active sites (mostly organic matter) with high specificity for $\mathrm{Pb}$, so when it is present these sites would not be occupied by others cations. According to these results, $\mathrm{Cd}$ may pose more threat to soils and groundwater of Port-au-Prince than $\mathrm{Pb}$ and $\mathrm{Cu}$. These results strongly suggest why Berti and Jacobs [43] found that soil loading of $\mathrm{Cd}, \mathrm{Ni}$, and $\mathrm{Zn}$ appeared to be of greater environmental concern than $\mathrm{Cr}, \mathrm{Cu}$, and $\mathrm{Pb}$ and that the first group could accumulate in the tissue of plants grown on sludge-treated plots [41].

\subsection{Competitive Adsorption}

Competitive adsorption studies were useful to assess the degree of interference posed common metal ions in the soil. The parameters of the JS and Langmuir extended models used in this study are summarized in Table 3. It was observed that $\mathrm{Pb}$ was always favorably sorbed on the soil over $\mathrm{Cu}$ and $\mathrm{Cd}$ in all the experiments. The experimental data from $\mathrm{Pb}$ and $\mathrm{Cu}$ bi-metal batch tests were better fitted than $\mathrm{Cd}$ with the JS model. The geochemical behavior of the three metals was evaluated following to their maximum adsorption capacity in the soil. These results indicated that competitive between the three metals have been reduced the adsorption capacity in the soil. Qin et al. [4] suggested that when two or 
more metal ions are present together, they may increase, decrease or not change the metal-ion adsorption capacity of the adsorbent. The competitive of $\mathrm{Cd}$ and $\mathrm{Pb}$ in acid soils was studied by Serrano et al. [15] and they noted that the co-existence of $\mathrm{Pb}$ and $\mathrm{Cd}$ reduces their tendency to be sorbed on the soil solid phases, thereby affecting the adsorption capacity of $\mathrm{Cd}$ to a greater extent than $\mathrm{Pb}$. The same phenomenon was observed by Morera et al. [44] using competitive adsorption isotherms to evaluate the mobility of $\mathrm{Cd}, \mathrm{Cu}, \mathrm{Ni}, \mathrm{Pb}$ and $\mathrm{Zn}$ in four soils differing in their physicochemical properties.

Table 3. Isotherm adsorption parameters for $\mathrm{Pb}, \mathrm{Cu}$ and $\mathrm{Cd}$ in monometal and bi-solutes systems on the soil $\left(q_{\max } \mathrm{L} ; q_{\max } \mathrm{JS}: \mathrm{mg} \cdot \mathrm{g}^{-1} ; b_{\mathrm{L}}, b_{\mathrm{JS}}, K_{\mathrm{F}}: \mathrm{L} \cdot \mathrm{mg}^{-1}\right)$.

\begin{tabular}{|c|c|c|c|c|c|c|c|}
\hline \multirow{2}{*}{ Metals } & \multirow{2}{*}{$\begin{array}{c}\text { Adsorption batch tests } \\
\text { Monometal } \\
\end{array}$} & \multicolumn{3}{|c|}{ Langmuir parameters } & \multicolumn{3}{|c|}{ Freundlich parameters } \\
\hline & & $q_{\max } L$ & $b_{\mathrm{L}}$ & $R_{\mathrm{L}}^{2}$ & $1 / n$ & $K_{\mathrm{F}}$ & $\boldsymbol{R}_{\mathrm{F}}^{2}$ \\
\hline $\mathrm{Pb}$ & $\mathrm{Cd}^{2+}$ & 3.64 & 0.37 & 0.91 & 1.41 & 0.85 & 0.91 \\
\hline $\mathrm{Cu}$ & $\mathrm{Cu}^{2+}$ & 0.70 & 1.81 & 0.91 & 0.78 & 0.45 & 0.92 \\
\hline \multirow[t]{3}{*}{$\mathrm{Cd}$} & $\mathrm{Cd}^{2+}$ & 0.63 & 0.05 & 0.90 & 1.01 & 0.03 & 0.89 \\
\hline & & \multicolumn{6}{|c|}{ Jain and Snoeyink parameters } \\
\hline & Bi-metal & $q_{\max } \mathrm{JS}$ & $b_{\mathrm{JS}}$ & $\boldsymbol{R}_{\mathrm{JS}}^{2}$ & $\Delta q_{\mathrm{JS}}(\%)$ & $r_{\mathrm{JS}}$ & \\
\hline \multirow{2}{*}{$\mathrm{Pb}$} & $\left(\mathrm{Pb}^{2+}-\mathrm{Cd}^{2+}\right)$ & 3.09 & 0.36 & 0.99 & 15.11 & 0.85 & \\
\hline & $\left(\mathrm{Pb}^{2+}-\mathrm{Cu}^{2+}\right)$ & 2.95 & 1.40 & 0.97 & 18.95 & 0.81 & \\
\hline \multirow{2}{*}{$\mathrm{Cu}$} & $\left(\mathrm{Cu}^{2+}-\mathrm{Cd}^{2+}\right)$ & 0.59 & 2.07 & 0.98 & 15.71 & 0.84 & \\
\hline & $\left(\mathrm{Cu}^{2+}-\mathrm{Pb}^{2+}\right)$ & 0.45 & 1.63 & 0.94 & 35.71 & 0.64 & \\
\hline \multirow{4}{*}{$\mathrm{Cd}$} & $\left(\mathrm{Cd}^{2+}-\mathrm{Pb}^{2+}\right)$ & 0.46 & 0.09 & 0.87 & 26.98 & 0.73 & \\
\hline & $\left(\mathrm{Cd}^{2+}-\mathrm{Cu}^{2+}\right)$ & 0.10 & 0.44 & 0.75 & 84.13 & 0.16 & \\
\hline & & \multicolumn{6}{|c|}{ Extended Langmuir parameters } \\
\hline & Tri-metal & $q_{\max } \mathbf{L E}$ & $b_{\mathrm{LE}}$ & $R_{\mathrm{LE}}^{2}$ & $\Delta q_{\mathrm{LE}}(\%)$ & $r_{\mathrm{LE}}$ & \\
\hline $\mathrm{Pb}$ & $\left(\mathrm{Pb}^{2+}-\mathrm{Cu}^{2+}-\mathrm{Cd}^{2+}\right)$ & 0.77 & 1.56 & 0.95 & 78.86 & 0.21 & \\
\hline $\mathrm{Cu}$ & $\left(\mathrm{Cu}^{2+}-\mathrm{Pb}^{2+}-\mathrm{Cd}^{2+}\right)$ & 0.43 & 1.79 & 0.98 & 38.57 & 0.61 & \\
\hline $\mathrm{Cd}$ & $\left(\mathrm{Cd}^{2+}-\mathrm{Pb}^{2+}-\mathrm{Cu}^{2+}\right)$ & 0.10 & 0.85 & 0.91 & 84.13 & 0.16 & \\
\hline
\end{tabular}

Mohan and Singh [45] have investigated the mutual effects of metals ions on their adsorption in multi-solute system by measuring the adsorption capacity ratio of one metal in multi-solute, $q_{i}^{\text {mix }}$ and the single-solute system, $q_{i}^{0}$, following this equation:

$$
r=q_{i}^{m i x} / q_{i}^{0}
$$

where $q_{i}^{0}$ and $q_{i}^{m i x}$ are the maximum amount sorbed according to monometal or multi-metal batch tests, respectively and $r$ is the adsorption capacity ratio. If $r>1$, metal $i$ enhanced the adsorption of the others ions. If $r=1$, metals had no effects on each other. If $r<1$, metal $i$ completed for with other metals for the adsorption sites of adsorbents. As showed in Table 3, all the values of $r$ are lower than 1 which indicates the mutual competitive effect of each metal in all the experiments. The $r$ values obtained from tri-metal batch tests are lower than those from bi-metal adsorption systems. These results indicated that the competitive adsorption processes depend on the quantity of metals ions from solid and liquid phases. 
The rate of adsorption reduction $(\Delta q)$ can be calculated following the Equation (10). This rate is the ratio of the difference between non-competitive and competitive adsorption observed at equilibrium:

$$
\Delta q(\%)=\left(\left(q_{i}^{0}-q_{i}^{\mathrm{m} i x}\right) / q_{i}^{0}\right) \times 100
$$

According the $\Delta q, \mathrm{~Pb}, \mathrm{Cu}$ and $\mathrm{Cd}$ ions had different competitive effect. For $\mathrm{Pb}$, the adsorption capacity was reduced by $15.11 \%, 18.95 \%$ and $78.86 \%$ respectively in $\left(\mathrm{Pb}^{2+}-\mathrm{Cd}^{2+}\right),\left(\mathrm{Pb}^{2+}-\mathrm{Cu}^{2+}\right)$ and $\left(\mathrm{Pb}^{2+}-\mathrm{Cu}^{2+}-\mathrm{Cd}^{2+}\right)$ systems. Similarly, the rate of adsorption equilibrium reduction of $\mathrm{Cu}$, comparing to its adsorption in monometal, decreased respectively by $15.71 \%, 35.71 \%$ and $38.57 \%$ in $\left(\mathrm{Cu}^{2+}-\mathrm{Cd}^{2+}\right)$, $\left(\mathrm{Cu}^{2+}-\mathrm{Pb}^{2+}\right)$ and $\left(\mathrm{Pb}^{2+}-\mathrm{Cu}^{2+}-\mathrm{Cd}^{2+}\right)$ systems. Finally, for $\mathrm{Cd}$, its adsorption capacity was reduced by $26.98 \%$ in $\left(\mathrm{Cu}^{2+}-\mathrm{Pb}^{2+}\right)$, by $84.13 \%$ in both $\left(\mathrm{Cd}^{2+}-\mathrm{Cu}^{2+}\right)$ and $\left(\mathrm{Pb}^{2+}-\mathrm{Cu}^{2+}-\mathrm{Cd}^{2+}\right)$ systems. Therefore, the similarity between the $\Delta q$ of $\mathrm{Cd}$ in $\left(\mathrm{Cd}^{2+}-\mathrm{Cu}^{2+}\right)$ and $\left(\mathrm{Pb}^{2+}-\mathrm{Cu}^{2+}-\mathrm{Cd}^{2+}\right)$ systems may indicate that $\mathrm{Cu}$ can suppress $\mathrm{Cd}$ adsorption greater than $\mathrm{Pb}$. According to the different rates of adsorption equilibrium reduction effect, the affinity sequence of the three metals for the soil in tri-metal adsorption systems is $\mathrm{Cu}^{2+}>\mathrm{Pb}^{2+}>\mathrm{Cd}^{2+}$. That means, when the three metals are in competition for the same sorption sites, $\mathrm{Cu}$ could displace $\mathrm{Pb}$ and $\mathrm{Pb}$ could displace $\mathrm{Cd}$. Indeed, the affinity order found from monometal adsorption batch tests, $\mathrm{Pb}^{2+}>\mathrm{Cu}^{2+}>\mathrm{Cd}^{2+}$, remained the same in competitive batch tests. In spite of the maximum capacity of $\mathrm{Pb}$ decreased related to competitive adsorption, it was mostly adsorbed on the soils over $\mathrm{Cu}$ and $\mathrm{Cd}$.

\section{Conclusions}

This study has shown in general that the soil of Port-au-Prince has a high capacity to sorb metal ions. Results from kinetics batch tests have shown the applicability of a pseudo-second order model to describe the adsorption rates of each metal on the soil. The ranked affinity of the selected metals for the soil was $\mathrm{Pb}^{2+}>\mathrm{Cu}^{2+}>\mathrm{Cd}^{2+}$ according to the maximum adsorption capacity obtained by the Langmuir model. Results from multimetal batch tests indicated that competition between heavy metals for sorption sites can reduce their maximum adsorption capacity on the soil. On the basis of results from this study, $\mathrm{Cd}$ may pose more threat to soils and groundwater of Port-au-Prince than $\mathrm{Pb}$ and $\mathrm{Cu}$. In short, regular groundwater samples and analysis may be carried out to assess changes in groundwater quality. It's necessary also to complete this study by coupling chemistry with a transport model for a better understanding of heavy metals transfer mechanisms to groundwater of Port-au-Prince.

\section{Acknowledgments}

The authors gratefully acknowledge Rhône-Alpes Region (France), the Prime Minister office of the Republic of Haiti and the Caribbean office of the "Agence Universitaire de la Francophonie" for their financial support.

\section{Conflicts of Interest}

The authors declare no conflict of interest. 


\section{References}

1. Bradl, H.B. Adsorption of heavy metal ions on soils and soils constituents. J. Colloid Interface Sci. 2004, 277, 1-18.

2. Siegel, F.R. Environmental Geochemistry of Potentially Toxic Heavy Metals; Springer: Berlin, Germany, 2002.

3. Usman, A.R.A. The relative adsorption selectivities of $\mathrm{Pb}, \mathrm{Cu}, \mathrm{Zn}, \mathrm{Cd}$ and $\mathrm{Ni}$ by soils developed on shale in New Valley, Egypt. Geoderma 2008, 144, 334-343.

4. Qin, F.; Wen, B.; Shan, X.-Q.; Xie, Y.-N.; Liu, T.; Zhang, S.-Z.; Khan, S.U. Mechanisms of competitive adsorption of $\mathrm{Pb}, \mathrm{Cu}$, and $\mathrm{Cd}$ on peat. Environ. Pollut. 2006, 144, 669-680.

5. Antoniadis, V.; Tsadilas, C.D.; Ashworth, D.J. Monometal and competitive adsorption of heavy metals by sewage sludge-amended soil. Chemosphere 2007, 68, 489-494.

6. Krishnamurti, G.S.R.; Naidu, R. Solid-solution equilibria of cadmium in soils. Geoderma 2003, 113, $17-30$.

7. Adhikari, T.; Singh, M.V. Sorption characteristics of lead and cadmium in some soils of India. Geoderma 2003, 114, 81-92.

8. Appel, C.; Ma, L. Concentration, $\mathrm{pH}$, and surface charge effects on cadmium and lead sorption in three tropical soils. J. Environ. Qual. 2002, 31, 581-589.

9. Hooda, P.S.; Alloway, B.J. Cadmium and lead sorption behavior of selected English and Indian soils. Geoderma 1998, 84, 121-134.

10. Jalali, M.; Moharrami, S. Competitive adsorption of trace elements in calcareous soils of western Iran. Geoderma 2007, 140, 156-163.

11. Kuo, S.; Baker, A.S. Sorption of copper, zinc, and cadmium by some acid soils. Soil Sci. Soc. Am. J. 1980, 44, 969-974.

12. Martinez, C.E.; McBride, M.B. Solubility of $\mathrm{Cd}^{2+}, \mathrm{Cu}^{2+}, \mathrm{Pb}^{2+}$, and $\mathrm{Zn}^{2+}$ in aged coprecipitates with morphous iron hydroxides. Environ. Sci. Technol. 1998, 32, 743-748.

13. Plassard, F.; Winiarski, T.; Petit-Ramel, M. Retention and distribution of three heavy metals in a carbonated soil: Comparison between batch and unsaturated column studies. J. Contam. Hydrol. 2000, 42, 99-111.

14. Sauvé, S.; Hendershot, W.; Allen, H.E. Solid-solution partitioning of metals in contaminated soils: Dependence on $\mathrm{pH}$, total metal burden, and organic matter. Environ. Sci. Technol. 2000, 34, 1125-1131.

15. Serrano, S.; Garrido, F.; Campbell, C.G.; Garcia-Gonzalez, M.T. Competitive sorption of cadmium and lead in acid soils of Central Spain. Geoderma 2005, 124, 91-104.

16. Trivedi, P.; Dyer, J.A.; Sparks, D.L. Lead sorption onto ferrihydrite. 1. A macroscopic and spectroscopic assessment. Environ. Sci. Technol. 2003, 37, 908-914.

17. Ponizovsky, A.A.; Allen, H.E.; Ackerman, A.J. Copper activity in soil solutions of calcareous soils. Environ. Pollut. 2007, 145, 1-6.

18. Fontes, M.P.F.; de Matos, A.T.; da Costa, L.M.; Neves, J.C.L. Compititive adsorption of Zn, Cd, Cu and $\mathrm{Pb}$ in three highly weathered Brazilian soils. Commun. Soil Sci. Plant Anal. 2000, 31, 2939-2958. 
19. Assessment of Human Exposures to Lead in Drinking Water. Available online: http://www.bvsde.paho.org/bvsAIDIS/PuertoRico29/ruth.pdf (accessed on 29 October 2013).

20. Emmanuel, E.; Angerville, R.; Joseph, O.; Perrodin, Y. Human health risk assessment of lead in drinking water : A case study from Port-au-Prince Haiti. Int. J. Environ. Pollut. 2007, 31, 280-291.

21. Emmanuel, E.; Pierre, M.G.; Perrodin, Y. Groundwater contamination by microbiological and chemical substances released from hospital wastewater: Health risk assessment for drinking water consumers. Environ. Int. 2009, 35, 718-726.

22. Metson, A.J. Methods of Chemical Analysis for Soil Survey Samples; New Zealand Department of Scientific and Industrial Research, Soil Bureau Bulletin: New Zealand, Wellington, 1956.

23. Equilibrium Sorption of $\mathrm{Pb}(\mathrm{II}), \mathrm{Cd}(\mathrm{II})$ and $\mathrm{Cu}(\mathrm{II})$ into Soil of Port-au-Prince: Single-Element System Studies. Available online: http://theses.insa-lyon.fr/publication/2010ISAL0122/these.pdf (accessed on 29 October 2013).

24. Jang, A.; Lee, S.-W.; Seo, Y.; Kim, K.-W.; Kim, I.S.; Bishop, P.L. Application of mulch for treating metals in urban runoff: Batch and column test. Water Sci. Technol. 2007, 55, 95-103.

25. Ho, Y.-S. Citation review of Lagergreen kinetic rate equation on adsorption reaction. Scientometrics 2004, 59, 171-177.

26. Achak, M.; Hafidi, A.; Ouazzani, N.; Sayadi, S.; Mandi, L. Low cost biosorbent "banana peel" for the removal of phenolic compounds from olive mill wastewater: Kinetic and equilibrium studies. J. Hazard. Mater. 2009, 166 117-125.

27. Banat, F.; Al-Asheh, S.; Al-Makhadmeh, L. Utilization of raw and activated date pits for the removal of phenol from aqueous solutions. Chem. Eng. Technol. 2004, 27, 80-86.

28. Goud, V.V.; Mohanty, K.; Rao, M.S.; Jayakumar, N.S. Phenol removal fromaqueous solutions using tamarind nut shell activated carbon: Batch and column study. Chem. Engin. Technol. 2005, 28, 814-821.

29. Fifi, U.; Winiarski, T.; Emmanuel, E. Groundwater Vulnerability towards Pollutants from Urban Stormwater in Developing Countries-Study of Heavy Metals Adsorption on a Representative Soil of Port-au-Prince, Haiti (in French); GRAIE: Lyon, France, 2010.

30. Jain, J.S.; Snoeyink, V.L. Adsorption from bisolute systems on active carbon. Water Pollut. Control Federation 1973, 45, 2463-2479.

31. Papageorgiou, S.K.; Katsaros, F.K.; Kouvelos, E.P.; Kanellopoulos, N.K. Prediction of binary adsorption isotherms of $\mathrm{Cu}^{2+}, \mathrm{Cd}^{2+}$ and $\mathrm{Pb}^{2+}$ on calcium alginate beads from single adsorption data. J. Hazard. Mater. 2009, 162, 1347-1354.

32. Cheung, C.W.; Porter, C.F.; McKay, G. Sorption kinetics for the removal of copper and zinc from effluents using bone char. Sep. Purif. Technol. 2000, 19, 55-64.

33. Keskinkan, O.; Goksu, M.Z.L.; Basibuyuk, M.; Forster, C.F. Heavy metal adsorption properties of a submerged aquatic plant (Ceratophyllum demersum). Bioresour. Technol. 2004, 92, 197-200.

34. Arias, M.; Pérez-Novo, C.; Lopez, E.; Soto, B. Competitive adsorption and desorption of copper and zinc in acids soils. Geoderma 2006, 133, 151-159.

35. Stumm, W.; Morgan, J.J. Aquatic Chemistry: Chemical Equilibria and Rates in Natural Waters, 3rd ed.; Wiley-Interscience Publication: Hoboken, NJ, USA, 1981.

36. Frimmel, F.H.; Huber, L. Influence of humic substances on the aquatic sorption of heavy metals on defined minerals phases. Environ. Int. 1996, 22, 507-517. 
37. Nagernaik, P.B.; Bhole, A.G.; Natarajan, G.S. Arsenic (II) removal by Adsorption rice husks carbon. Int. J. Environ. Stud. 2002, 5, 1097-1164.

38. McKay, G.; Otterburn, M.S.; Sweeney, A.G. The removal of color from effluent using various adsorbents - IV silica: Equilibria and column studies. Water Res. 1980, 14, 21-27.

39. Tellan, A.C.; Owalude, S.O. Some Langmuir and Freundlich parameters of adsorption studies of chlorpheniramine maleate. Res. J. Appl. Sci. 2007, 2, 875-878.

40. Elliott, H.A.; Liberat, M.R.; Huang, C.P. Competitive adsorption of heavy metals by soils. J. Environ. Qual. 1986, 15, 214-219.

41. Gomes, P.C.; Fontes, M.P.F.; da Silva, A.G.; de S. Mendonça, E.; Netto, A.R. Selectivity sequence and competitive adsorption of heavy metals by Brazilian soils. Soil Sci. Soc. Am. J. 2001, 65, $1115-1121$.

42. Yong, R.N.; Mohamed, A.M.O.; Warkentin, B.P. Principles of Contaminant Transport in Soils; Elsevier: Amsterdam, The Netherlands, 1992.

43. Berti, W.R.; Jacobs, L.W. Distribution of trace elements in soil from repeated sewage sludge application. J. Environ. Qual. 1998, 27, 1280-1286.

44. Morera, M.T.; Echeverría, J.C.; Mazkiarán, C.; Garrido, J.J. Isotherms and sequential extraction procedures for evaluating sorption and distribution of heavy metals in soils. Environ. Pollut. 2001, $113,135-144$.

45. Mohan, D.; Pittman, C.U., Jr.; Steele, P.H. Single, binary and multi-component adsorption of copper and cadmium from aqueous solutions on Kraft lignin — a biosorbent. J. Colloid Interface Sci. 2006, 297, 489-504.

(C) 2013 by the authors; licensee MDPI, Basel, Switzerland. This article is an open access article distributed under the terms and conditions of the Creative Commons Attribution license (http://creativecommons.org/licenses/by/3.0/). 